\title{
Effect of Knowledge on COVID-19 and Hygiene Behavior on the Mental Health of Cosmetology Students
}

\author{
Mi-Jeung Ahn \\ Department of Nursing, Andong National University, Andong-si, Gyeongsangbuk-do, Korea
}

Corresponding author: Mi-Jeung Ahn, Department of Nursing, Andong National University, 1375, Gyeongdong-ro, Andongsi, Gyeongsangbuk-do 36729, Korea

Tel.: +82548206715

Fax: +82548206730

Email: mjahn@korea.ac.kr

Received November 04, 2021

Revised December 01, 2021

Accepted December 06, 2021

Published December 30, 2021

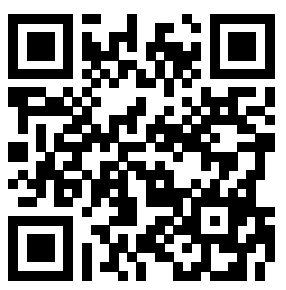

\begin{abstract}
Purpose: This study aimed to confirm the knowledge on COVID-19 and hygiene behavior of cosmetology students and identify factors affecting mental health. Methods: In the analysis, SPSS/WIN program was used. Univariate analysis was used for knowledge COVID-19, preventive behavior, and mental health, and stepwise multiple regression was used for factors affecting mental health. Results: The factors affecting the mental health of cosmetology students were identified as knowledge related to COVID-19, subjective health perception, and part-time job. Conclusion: In this study, 34.9\% and $36.2 \%$ of the borderline and severe groups of anxiety and depression respectively, which are subfactors of the mental health of cosmetology students, were identified. In future studies, it is considered necessary to expand sample and the influencing factors.
\end{abstract}

Keywords: COVID-19, Knowledge, Hygiene behavior, Mental health, Cosmetology student

\section{Introduction}

Covid-19 (Coronavirus Desease-19)에 대응하기 위해 세계보건 기구(World Health Organization, WHO)에서는 국제공중보건비상사 태를 선포하였고, 이미 20 세기말 세계보건기구(WHO)는 '21세기는 전 염병의 시대'라고 규정한 사례가 있다(Shim, 2020). 20세기부터 인수 공통 감염병을 중심으로 에볼라 바이러스(Ebola virus), 사스(Severe Acute Respiratory Syndrome, SARS), 신종플루(Novel swine-origin influenza A, H1N1), 메르스(Meddle East Respiratory Syndrome, $\mathrm{MERS})$ 에 이어 최근 Covid-19에 이르기까지 신종전염병 출현이 지속 되고 있다.

Covid-19의 지속적인 상황으로 보건의료와 연관이 있는 서비스 산 업인 뷰티산업의 예비전문가로서 역량을 준비하는 뷰티전공 대학생은 건강과 사회환경변화에 민감할 필요가 있으며, Covid-19에서 지식 수준은 일반인 보다 높게 요구 되어진다.

신종 감염병의 유행으로 감염병 예방을 위한 행동지침에 기침이나 재채기를 할 때 옷 소매로 가리고 기침하기를 권고하고, 손 씻기를 권
고하고 있다(Shin, 2019). 이런 행동은 위생행위와 관련이 있다. 위생 이란 건강의 증진을 도모하고 질병의 예방에 도움을 주며, 개인위생을 청결히 해서 세균의 전파 및 감염을 예방하고자 하는 것이다(Kim et al., 2012). 부족한 손위생과 개인위생, 가정에서의 위생이 감염성 질 환의 발생위험성을 증가시킨다(Kim et al., 2012).. 이는 위생행위가 감 염성 질환의 예방에 중요하다는 것을 의미하고, 감염성 질환을 예방하 기 위해서는 위생행위의 실천이 중요하다고 할 수 있다.

Covid -19 와 같은 신종전염병의 출현과 장기화로 국내외의 정치. 경제, 사회에 혼란이 가중되어 발생하고 있으며, 일반인과 의료인의 정신건강에 영향을 미치는 연구가 보고되고 있다(Lee et al., 2020). Covid-19의 범 유행상황으로 우리사회는 '사회적 거리두기'와 '생활 속 거리두기'를 번갈아 가며 시행해 오고 있다. 이 결과로 경제적 사회 적 활동이 지속적으로 축소됨에 따라 정신건강에 직·간접적으로 영향 을 미칠 수 있다(Holmes et al., 2020). 또한 Covid-19의 범 유행상황 에서 뷰티전공 대학생들은 교육과정에 실습 교과목이 많아 정부의 방 역지침과 대학의 방역지침에 따라 대응단계를 준수하며 수업운영을 해야 하므로 학생들은 학업에 대한 심리적 부담감과 이에 수반되는 스 
트레스가 높아질 수 있다. 심리적 부담감과 활동의 제한으로 개인은 스트레스, 우울, 불안, 분노 등 다양한 정신적 문제를 유발 할 수 있다 (Holmes et al., 2020). 사회적 거리두기와 생활 속 거리두기를 실천 하기 위해 대학에서 비대면 원격수업과 온라인 시험을 실시하고 있으 며, 사회 전반적인 측면에서 활동의 제약이 이루어 지고 있는 실정이 다. 이런 상황에서 불안, 우울과 외로움이 증가하며, 대학생 시기는 특 별히 취약한 시기이다(Lee, 2020). 또한 대학생 시기는 활발한 활동을 하는 시기이며, 밀집된 강의실에서 학습하는 시기이다. 실습과정과 현 장에서 1 차적 대면활동이 많은 뷰티전공 대학생들은 타 전공 대학생 들에 비해 Covid-19에 대한 지식과 위생행위에 대한 수준을 확인하고 정신건강에 영향을 주는 요인 확인이 더욱더 필요하다.

Covid-19와 관련된 선행연구를 살펴 보면 대학생의 지식과 예방행 동에 관한 연구(Kim et al., 2021; Kim et al., 2020), 정신건강에 미 치는 영향(Kim \& Kang, 2021), 간호대학생을 대상으로 예방행위 영 향요인(Lee et al., 2021), 간호대학생을 대상으로 Covid-19 지식, 불 안, 예방행위수행정도에 대한 연구(Hwang \& Lee, 2020)가 대부분이 었다. 뷰티전공 대학생을 대상으로 한 연구는 Covid-19에 대한 지식, 태도, 실천에 관한 연구(Ahn, 2021), 손씻기 지식과 수행의 관계 연 구(Ahn \& Park, 2019)연구가 있어 뷰티 전공 대학생을 대상으로 한 Covid-19와 관련된 지식과 위생행위가 정신건강에 미치는 영향에 관 한 연구는 매우 의미가 있다고 생각된다.

이에 본 연구는 뷰티전공 대학생을 대상으로 Covid-19에 대한 지 식과 위생행위를 확인하고 정신건강에 미치는 요인을 확인하여 뷰티 전공 대학생들의 정신건강증진을 위한 중재 방안을 모색하고 프로그 램 개발의 기초자료를 제공하는데 목적이 있다.

본 연구의 구체적 목적은 다음과 같다.

1) 뷰티전공 대학생의 Covid-19에 대한 지식, 위생행위와 정신건강 을 확인한다.

2) 일반적 특성에 따른 뷰티전공 대학생의 Covid-19에 대한 지식, 위생행위와 정신건강를 확인한다.

3) 뷰티전공 대학생의 Covid-19에 대한 지식, 위생행위와 정신건강 의 상관관계를 확인한다.

4) 뷰티전공 대학생의 정신건강에 영향을 미치는 요인을 확인한다.

\section{Methods}

\section{1.연구 설계}

본 연구는 뷰티전공 대학생을 대상으로 Covid-19에 대한 지식, 위 생행위와 정신건강의상관관계를 확인하고 정신건강에 영향을 미치는 지를 파악하기 위한 서술적 연구 이다.

\section{2. 연구 수집 방법 및 대상}

본 연구는 $\mathrm{S}$ 시에 소재한 일 대학의 뷰티전공 대학생을 대상으로
2021년 5월 24일에서 6월 11일까지 설문조사 하였다. 설문조사는 Covid-19로 인한 사회적 거리 두기 기간이라 비대면 온라인 설문 참 여 방법으로 조사하였다. 연구대상자의 수는 $G *$ power program 3.19 를 이용하여 산정 시, 상관관계 양측 검정에서 유의수준 $(\alpha) 0.05$, 보통

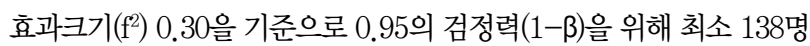
이상이 요구 되었다. 설문 응답의 탈락률 $15 \%$ 를 고려하여 160 부를 배 포하였으며 160 명이 응답하였다. 이중 응답한 남학생의 수가 적어 통 계적으로 영향을 미칠 것을 고려하여 남학생 8 명을 제외하고 152 부를 분석하였고, 최소 표본 수를 충족하였다.

\section{3. 연구 도구}

1) Covid-19에 대한 지식

Covid-19에 대한 지식에 대한 문항은 총 13항으로 구성되었다. 지 식에 대한 문항은 Provenzano et al. (2020)이 간호 대학생을 대상으 로 개발한 도구를 사용하였고, 원 도구를 1 차로 한국어로 번역한 후 성인간호학 전공 교수 1 인과, 역학전공 교수 1 인, 뷰티전공 교수 1 인이 원 도구와의 일치도를 논의하였다. 뷰티전공 대학생 25 명에게 Pilot Study(예비조사)를 시행한 후 2차로 전문가 회의를 진행하여 문 항을 이해하기 쉽도록 수정하였다. 2 차례의 전문가 회의로 내용 타당 도를 확보하였고, content validity index (CVI)는 0.97이었다. 도구의 지식측정 문항 신뢰도는 Cronbach's $\alpha$ 값 0.81 이었다.

문항의 내용은 Covid-19의 의미와 감염경로, 병인과 증상에 대한 지식 정도로 구성되었다. 각 문항에 '정답은 1점을 부여하고, '오답'과' 잘 모르겠다'는 0 점을 부여한 후 100 점 만점으로 환산하여 점수를 산 출하였다. 총점의 범위는 0-100점이며 점수가 클수록 Covid-19에 대한 지식 정도가 높은 것을 의미하며, 본 연구에서의 지식문항의 신 뢰도는 Cronbach's $\alpha$ 값이 0.86 이었다.

\section{2)위생행위}

Covid-19에 대한 위생행위를 확인하기 위해서 Stevenson et al. (2009)이 개발한 위생행위(hygiene inventory 23, HI 23)을 Kim et al. (2012)의 연구에서 번역하여 사용한 측정도구를 사용하였다. 위 생행위는 총 23 문항이며, 5 개의 하위행위로 구성되어 있다. 하위행 위는 일반위생 8 문항, 가정위생 3 문항, 식품관련위생 3 문항, 손 위생 5 문항, 개인위생 4 문항으로 구성되어 있다. 4점 Likert 척도로 구성 되어 있으며 응답은 전혀 1점에서 항상 4 점까지 수행빈도를 측정하 여 각 항목의 합계점수가 높을수록 위생행위를 잘 수행하는 것을 의 미한다. Stevenson et al. (2009)의 연구에서 Cronbach's $\alpha$ 값은 0.85 였고, 본 연구에서의 Cronbach's $\alpha$ 값은 0.82이었다.

\section{3) 정신건강}

본 연구에서 정신건강을 측정하기 위한 도구는 Zigmond \& Snaith (1983)이 개발한 도구를 Oh et al. (1999)이 번안하여 표준화한 도구 (hospital anxiety and depression scale, HADS)를 사용하였다. 이 
도구는 비 정신과 환자의 불안과 우울을 측정하기 위해 개발된 도구 로 외국에서는 표준화 되고 타당도 검증이 되어 있으며 다른 척도와 의 비교 검증도 되어 있는 도구이다(Oh et al., 1999). 유럽과 미국 등에서도 표준화 되어 타당도 검증이 되어 있고 일반인들의 정신건강 측정에 매우 유용하다(Montazeri et al., 2003). 전체 문항 수는 14 문항이며 하위요인으로 불안 7문항, 우울 7문항으로 구성되어 있으 며 0점에서 3점까지의 4점 Likert 척도상에서 응답한다. 불안과 우울 에서 최고 점수는 21점으로 0-7점 사이는 정상, 8-10점 사이는 경 계선, 11점 이상은 중증으로 구분된다. Oh et al. (1999)의 연구에서 Cronbach's $\alpha$ 값은 불안 0.89 , 우울 0.86 으로 보고되었으며. 본 연구 에서 Cronbach's $\alpha$ 값은 불안 0.87 , 우울 0,83 으로 나타났다.

\section{4. 분석 방법}

수집된 자료는 SPSS/WIN 25 프로그램을 사용하여 사용하여 분석 하였고, 자료분석 방법은 다음과 같다.

-대상자의 특성, Covid-19에 대한 지식, 위생행위, 정신건강은 기술통계로 분석하였고, 측정도구의 신뢰도는 KR20, Cronbach's $\alpha$ coefficients로 확인 하였다.

-대상자의 특성에 따른 Covid-19에 대한 지식, 예방행위, 정신건 강 차이는 independent $t$-test, $\mathrm{ANOVA}$ 를 사용하였고, 사후검정은 Scheffé test로 검정하였다.
-Covid-19에 대한 지식, 예방행위, 정신건강의 상관관계는 Pearson correlation coefficients로 확인 하였다.

-Covid-19관련 정신건강에 영향을 미치는 요인은 Stepwise multiple regression으로 확인 하였다.

\section{5. 윤리적 고려}

본 연구는 연구윤리 지침에 따라 대상자에게 연구의 목적과 설문 지 작성 요령에 대한 자세한 설명을 실시하였다. 설명 후 대상자에게 연구 참여 동의서를 받고 자발적 의사에 따라 진행하였다. 연구 진행 단계 중 어느 때나 연구참여를 거부하거나 중단할 수 있음을 고지하 고 어떠한 불이익도 없음을 설명하였다. 수집된 자료는 연구 이외의 목적으로 활용되지 않으며, 연구 종료 후 폐기됨을 설명하였다. 설문 조사는 10-15 $\mathrm{min}$ 정도 소요되었고, 온라인 설문 조사 후 설문 참여 대상자에게 답례품을 제공하였다.

\section{Results}

\section{1. 대상자의 일반적 특성에 따른 Covid-19에 대한 지식, 위생행 위, 정신건강}

연구 대상자는 2 학년이 44 명(28.9\%)로 가장 많았고 1학년, 3학년

Table 1. Knowledge on COVID-19, hygiene behavior, and mental health according to the general characteristics of the subject ( $\mathrm{N}=152)$

\begin{tabular}{|c|c|c|c|c|c|c|c|c|}
\hline \multirow{2}{*}{ Variables } & \multirow{2}{*}{ Categories } & \multirow{2}{*}{$\mathrm{N}(\%)$} & \multicolumn{2}{|c|}{ COVID-19 related knowledge } & \multicolumn{2}{|c|}{ Hygiene behavior } & \multicolumn{2}{|c|}{ Mental health } \\
\hline & & & $\mathrm{M} \pm \mathrm{SD}$ & $t \operatorname{or} F(p)$ & $\mathrm{M} \pm \mathrm{SD}$ & $t \operatorname{or} F(p)$ & $\mathrm{M} \pm \mathrm{SD}$ & $t$ or $F(p)$ \\
\hline Gender & Female & $152(100.0)$ & $84.70 \pm 4.53$ & & $3.49 \pm 0.34$ & & $9.68 \pm 3.63$ & \\
\hline \multirow{4}{*}{ Grade } & Freshmana & 37 (24.3) & $83.43 \pm 4.51$ & \multirow{4}{*}{$\begin{array}{c}5.44(0.001) \\
n / a\end{array}$} & $3.28 \pm 1.28$ & \multirow{4}{*}{$\begin{array}{c}19.09(0.000) \\
n / a\end{array}$} & $7.30 \pm 6.64$ & \multirow{4}{*}{$\begin{array}{c}10.34(0.000) \\
b, c>a, d\end{array}$} \\
\hline & Sophomoreb & $44(28.9)$ & $83.14 \pm 4.26$ & & $3.39 \pm 1.37$ & & $12.64 \pm 6.03$ & \\
\hline & Juniorc & $37(24.3)$ & $85.35 \pm 4.64$ & & $3.54 \pm 1.29$ & & $10.76 \pm 2.98$ & \\
\hline & Seniord & $34(22.4)$ & $85.11 \pm 5.01$ & & $3.78 \pm 1.13$ & & $7.29 \pm 3.84$ & \\
\hline \multirow{3}{*}{$\begin{array}{l}\text { Subjective health } \\
\text { status }\end{array}$} & Poora & $67(44.1)$ & $82.67 \pm 4.97$ & \multirow{3}{*}{$\begin{array}{c}6.68(0.002) \\
a<b, c\end{array}$} & $3.48 \pm 1.24$ & \multirow{3}{*}{$0.032(0.254)$} & $17.0 \pm 5.15$ & \multirow{3}{*}{$\begin{array}{c}36.37(0.000) \\
a>c\end{array}$} \\
\hline & Averageb & $67(44.1)$ & $85.07 \pm 4.76$ & & $3.49 \pm 1.39$ & & $10.61 \pm 4.38$ & \\
\hline & Goodc & $18(11.8)$ & $85.60 \pm 5.26$ & & $3.51 \pm 1.34$ & & $6.79 \pm 4.75$ & \\
\hline \multirow{2}{*}{ Part-time job } & Yes & $40(26.3)$ & $82.62 \pm 4.55$ & \multirow{2}{*}{$-1.09(0.276)$} & $3.53 \pm 0.29$ & \multirow{2}{*}{$2.56(0.000)$} & $10.59 \pm 5.82$ & \multirow{2}{*}{$3.40(0.001)$} \\
\hline & No & $112(73.7)$ & $81.93 \pm 4.47$ & & $3.37 \pm 0.42$ & & $7.15 \pm 4.18$ & \\
\hline \multirow{2}{*}{$\begin{array}{l}\text { Need for COVID-19 } \\
\text { education }\end{array}$} & Need & $113(74.3)$ & $84.76 \pm 5.56$ & \multirow{2}{*}{$0.870(0.386)$} & $3.56 \pm 0.31$ & \multirow{2}{*}{$14.45(0.000)$} & $9.93 \pm 5.75$ & \multirow{2}{*}{$1.91(0.194)$} \\
\hline & Dose not need & $39(25.7)$ & $81.52 \pm 4.47$ & & $3.21 \pm 0.39$ & & $8.97 \pm 5.28$ & \\
\hline \multirow{3}{*}{$\begin{array}{l}\text { Mental health } \\
\text { Anxiety }\end{array}$} & Normal & 99 (65.1) & & & & & & \\
\hline & Borderline & $43(28.3)$ & & & & & & \\
\hline & Sever & $10(6.6)$ & & & & & & \\
\hline \multirow{3}{*}{ Depression } & Normal & $97(63.8)$ & & & & & & \\
\hline & Borderline & $53(34.8)$ & & & & & & \\
\hline & Sever & $2(1.4)$ & & & & & & \\
\hline
\end{tabular}

*Scheffe' test. 
이 37명(24.3), 4학년이 34명(22.4\%)의 순이였다. 주관적인 건강인 식에서는 불건강하다고 인식한 군과 보통이다로 인식한 군이 67 명 (44.1\%)로 나타났고, 건강하다고 인식한 군은 18 명(11.8\%)로 나타났 다. 현재 아르바이트를 하지 않는 학생이 112 명(73.7\%)로 더 많이 나 타났고, Covid-19에 대한 교육의 필요하다는 학생이 113명(74.3\%) 로 더 높게 나타났다(Table 1).

대상자의 특성에 따른 Covid-19에 대한 지식은 학년 $(F=5.44$, $p<0.001)$ 과 주관적 건강인식 $(F=6.68, p<0.002)$ 에서 통계적으로 유 의하였다. 사후검증 결과 학년에서는 집단 분리가 되지 않아 해당 없 음으로 나왔으며, 주관적인 건강인식에서는 건강하다고 인식하는 군 이 부정적으로 인식하는 군 보다 Covid-19에 대한 지식이 높게 나타 났다.

대상자의 특성에 따른 위생행동은 학년( $F=19.09, p<0.000)$, 아르 바이트를 하는 학생 $(t=2.56, p<0.000)$ 에게서, Covid-19에 대한 교 육의 필요하다는 학생에게서 통계적으로 유의하게 나타났다. 위생행 동에서 학년에 대한 사후검증 결과 학년에서는 집단 분리가 되지 않 아 해당 없음으로 나왔다.

대상자의 특성에 따른 정신건강은 학년( $F=10.34, p<0.000)$ 과 주 관적 건강인식 $(F=36.37, p<0.000)$, 아르바이트 하는 학생 $(t=3.40$, $p<0.001)$ 에게서 통계적으로 유의하게 나왔다. 사후검증결과 학년에 서는 2 학년 3 학년이 1 학년 4학년에 비해 정신건강이 불건강하였고, 주관적 건강인식은 불건강하게 인식하는 학생들이 건강하다고 인식
하는 학생들보다 정신건강이 불건강하였다(Table 1).

대상자들의 정신건강은 하위요인인 불안에서 경계선 군과 심각한 군이 53 명(34.9\%)로 나타났고, 우울에서는 경계선 군과 심각한 군이 55 명(36.2\%)로 나타났다(Table 1).

\section{2. 대상자의 Covid-19에 대한 지식, 위생행위, 정신건강}

연구 대상자들의 Covid-19에 대한 지식은 100 점으로 환산 한 결 과 평균 84.7점으로 나타났다. 개인위생 행동의 전체 평균 점수는 3.49 점이었고, 하위요인은 식품관련 평균 점수가 3.78 로 가장 높았 다. 정신건강의 전체 평균 점수는 9.68점으로 나타났고 하위요인인 불안은 6.91점, 우울은 5.77점으로 나타났다(Table 2).

\section{Covid-19에 대한 지식, 위생행위, 정신건강의 상관관계}

연구대상자의 Covid-19에 대한 지식, 위생행위와 정신건강의 상 관관계에서는 Covid-19에 대한 지식은 정신건강과 음의 상관관계 $(\mathrm{r}=-0.192, p<0.000)$ 를 나타내었고, 위생행위도 정신건강의 하위요 인인 불안과 음의 상관관계( $\mathrm{r}=-0.240, p<0.003)$ 를 나타내었다(Table 3).

\section{4. 정신건강에 영향을 미치는 요인}

연구대상자들의 정신건강에 영향을 미치는 독립적인 요인을 확인 하기 위해 다중회귀분석을 한 결과는 Table 4 와 같다. 단변량 분석

Table 2. Subject's knowledge on COVID-19, hygiene behavior, and mental health

$(\mathrm{N}=152)$

\begin{tabular}{|c|c|c|}
\hline Variables & $\mathrm{M} \pm \mathrm{SD}$ & Range \\
\hline COVID-19 related knowledge & $84.70 \pm 4.53$ & $1-100$ \\
\hline Hygiene behavior & $3.49 \pm 0.34$ & 1-4 \\
\hline General hygiene & $3.64 \pm 1.35$ & \\
\hline Household hygiene & $3.25 \pm 1.08$ & \\
\hline Food-related hygiene & $3.78 \pm 1.32$ & \\
\hline Hand hygiene & $3.49 \pm 1.29$ & \\
\hline Personal hygiene & $3.20 \pm 1.69$ & \\
\hline Mental health & $9.68 \pm 3.65$ & $0-42$ \\
\hline Anxiety & $6.91 \pm 3.12$ & $0-21$ \\
\hline Depression & $5.77 \pm 3.11$ & $0-21$ \\
\hline
\end{tabular}

Table 3. Correlation between knowledge on COVID-19, hygiene practices and mental health

( $N=152)$

\begin{tabular}{lcc}
\hline Variables & COVID-19 related knowledge & Hygiene behavior \\
\cline { 2 - 3 } COVID-19 related knowledge & 1 & $r(p)$ \\
Hygiene behavior & $0.128(0.127)$ & 1 \\
Mental health & $-0.192(0.000)^{*}$ & $0.140(0.085)$ \\
Anxiety & $-0.245(0.000)^{* *}$ & $-0.240(0.003)^{* *}$ \\
Depression & $-0.301(0.000)^{* *}$ & $0.013(0.578)$ \\
\hline
\end{tabular}

${ }^{* *} p<0.01$. 
에서 정신건강에 통계적으로 유의한 차이가 있는 것으로 확인된 변 수인 학년과 주관적 건강인식, 현재 아르바이트유무와 상관분석에서 상관관계가 있는 것으로 나타난 Covid-19에 대한 지식, 위생행위를 독립변수로 하고 정신건강을 종속변수로 하여 단계적 회귀분석을 하 였다. 학년과, 주관적 건강인식, 현재 아르바이트 유무 변수는 더미 변수화 하여 분석하였다. 독립변수에 대한 회귀분석의 가정을 검정 하기 위해 다중공선성과 잔차 및 특이 값을 확인 하였다. 그 결과 독 립변수들 간의 상관계수는 0.19-0.26으로 나타나 0.80이상의 설명 변수가 없어 변수들간의 독립성이 확인되었다. 다중공선성을 확인한 결과 공차 한계가 $0.68-0.79$ 로 1.0 이하 0.1 이상으로 확인되었고, 분 산팽창인자(variance inflation factor, VIF)가 1.05-1.44로 나타나 10 이상을 넘지 않아 다중공선성의 문제는 없었다. 잔차의 가정을 충 족하기 위한 검정결과 오차의 정규성과 등분산성도 만족하여 회귀식 의 가정이 모두 충족되었다.

대상자의 정신건강에 영향을 미치는 유의한 변수는 Covid-19에 대한 지식 $(\beta=0.122, p<0.002)$, 주관적 건강인식 $(\beta=0.625, p<0.000)$, 현재 아르바이트 유무 $(\beta=-0.346, p<0.002)$ 가 확인되었다. 이들 변 수들의 설명력은 $46.1 \%$ 로 나타났다 $(F=26.83, p<0.000)$.

\section{Discussion}

본 연구는 Covid-19에 관한 지식과 위생행위가 뷰티전공 대학생 들의 정신건강에 미치는 영향요인을 확인하고 자 수행되었다.

본 연구에서 뷰티전공 대학생들의 Covid-19에 대한 지식은 100 점으로 환산하여 84.7점으로 나타났다. 동일한 도구를 사용한 $\mathrm{Ahn}$ (2021)의 연구에서는 85점으로 나타나 유사한 결과를 보였고, 간호 대학생을 대상으로 한 선행연구(Provenzano et al., 2020)의 95점 보 다는 낮게 측정되었다. 일반 대학생을 대상으로 한 선행연구(Kim et al., 2021)의 78.4점 보다는 높게 나타났다. 이는 뷰티전공의 특성상 개인을 대상으로 하고 신체 접촉이 많은 서비스와 관련된 실습교과목 이 많아 위생과 보건에 대한 지식이 높은 것으로 생각 되어지고, 또 다른 이유는 Covid-19의 범 유행의 장기화로 초기에 비해 다양한 미 디어와 학교 교육에서 정보가 공유되고 습득되었기 때문이라고 생각
된다. 향후 Covid-19 지식과 관련된 연구가 범 유행의 시기와 다른 변수들과의 관계를 통한 효과성 등에 대한 세부적 연구가 확대되어야 할 필요가 있다. 대상자들의 주관적 건강에 대한 인식은 건강하다고 인식한 경우가 불건강하다로 인식한 경우보다 Covid-19에 대한 지 식점수가 높았고 이는 Shin (2019)의 연구와 유사한 결과를 나타내 었다. 주관적 건강에 대한 인식은 자기효능감과 유사하게 측정되는 변수로 건강에 대한 긍정적 인식이 능동적인 학습으로 연결되어 나타 난 것으로 생각된다.

본 연구에서 대상자들의 위생행위는 4점 만점에 3.49점으로 나타 났고 대학생을 대상으로 한 선행연구(Shin, 2019; Stevenson et al., 2009)에서 나타난 2.80점, 2.90점 보다는 높게 나타났다. 이는 앞의 선행연구는 Covid-19의 범유행 이전의 연구이기 때문에 위생행위에 대한 대중적 정보와 홍보 및 교육이 현재의 상황보다 적었던 것이 본 연구보다 위생행위에 대한 낮은 평균 점수를 나타낸다고 생각된다. 위생행위에 대한 연구는 주로 손 씻기 이행과 교육에 대한 연구가 대 부분이며, 전반적인 위생행위에 대한 연구가 부족한 실정이다. 현재 Covid-19의 상황에서 위생에 대한 인식의 중요성을 실감하고 있고 위생행위 전체를 포함하는 연구가 확대되어야 할 것으로 사료된다.

정신건강에서 가장 흔한 질환이 불안장애와 우울장애 이다. 본 연 구에서는 대상자들의 정신건강을 확인하고 신종전염병 상황에서 뷰 티전공 대학생들의 정신건강에 영향을 미치는 요인을 확인하고자 하 였다. 본 연구에서 정신건강에 영향을 주는 요인으로는 Covid-19 에 대한 지식 $(\beta=0.625, p<0.000)$, 주관적 건강인식 $(\beta=-0.346$, $p<0.000)$, 현재 아르바이트 유무( $\beta=0.122, p<0.002)$ 가 확인되었다. Covid-19상황에서 정신건강과 관련된 선행연구에서 정신건강문제 를 다룬 연구(Sim, 2020), 대학생의 정신건강실태(Park et al., 2021) 연구가 있었고 정신건강 즉 불안과 우울을 포함하는 연구는 없는 실 정으로 직접적인 비교는 어려웠다. 청년세대의 정신건강에 미치는 영향을 확인한 연구(Kim \& Kang, 2021)가 있었으나 연구대상자의 주관적 정신건강을 단일문항을 변수로 하여 수행한 연구로 본 연구와 는 직접적인 비교가 어려웠다.

지난 2019년 12 월 중국 우한에서 시작된 Covid-19의 확산과 세 계적인 범 유행은 거의 2 년 가까이 지속되고 있으며 하버드에서 예 측 연구(Kissler et al., 2020)한 바에 의하면 2022년까지 지속적 혹

Table 4. Factors influencing mental health

$(\mathbf{N}=152)$

\begin{tabular}{lccccc}
\hline Variables & $\mathrm{B}$ & $\mathrm{SE}$ & $\beta$ & $t$ & $p$ \\
(Constant) & & & & & \\
CoviD-19 related Knowledge & 0.44 & 0.226 & 0.122 & 9.04 & 0.002 \\
Part-time job & -0.41 & 0.705 & -0.346 & -5.49 & 0.000 \\
Subjective health status & 5.12 & 0.510 & 0.625 & 1.98 & 0.000 \\
& & $\mathrm{R}^{2}=0.479$, Adj R ${ }^{2}=0.461, F=26.83, p<0.000$ & & \\
\hline
\end{tabular}

Including variables in stepwise method: COVID-19 related knowledge, hygiene behavior, mental health. Grade=dummy variable (senior=1), Subjective health status=dummy variable (poor=1); Part-time job=dummy variable (no=1). Adj, adjusted; SE, standard error. 
은 간헐적 거리두기가 필요할 것으로 예측하였다. 따라서 뷰티전공 대학생의 정신건강에 영향을 주는 요인을 좀 더 세부적으로 확인하여 정신건강상태를 관리해야 할 것이다. 뷰티전공 대학생을 대상으로 체계적인 감염병 교육 프로그램과 정신건강의 하위요인인 불안과 우 울 요소를 확인하여 프로그램을 운영한다면 교육 현장에서 긍정적인 효과와 활용이 가능 할 것이다.

본 연구의 제한점은 첫째, 일개 대학생을 중심으로 연구를 하여 일 반화가기 어려운 문제가 있다. 이를 보완하기 위해 향후 연구 대상자 를 확대하여 연구할 필요가 있다. 둘째 뷰티 전공의 특성상 여학생이 많아 남학생들과의 비교가 어려웠다. 선행연구들(Shin, 2019; Kim et al., 2012; Stevenson et al., 2009; Anderson et al., 2008)에서 는 위생행위에 영향을 주는 변수로 성별이 포함되었다. 향후 연구대 상자를 남성의 표본 수를 확대한 연구설계를 통하여 연구할 필요가 있다. 따라서 확대 추가된 연구를 통하여 본 연구의 결과를 검증하고 더 발전하여 기타 영향요인에 대한 규명이 필요함을 제언한다.

\section{Conclusion}

본 연구는 온라인 설문을 통하여 Covid-19의 지식과, 위생행위가 뷰티전공 대학생의 정신건강에 영향을 주는 요인을 확인하였다는 점 에서 의의가 있다. 특히 뷰티전공 대학생들의 정신건강에서 불안에 서 경계선 군과 심각 군이 $34.9 \%$ 로 확인 되었고, 우울에서 경계선 군 과 심각 군이 $36.2 \%$ 를 나타났다는 것에 관심을 가질 필요가 있다. 정 신건강에 영향을 주는 요인으로 나타난 Covid-19관련 지식, 주관적 건강인식, 아르바이트를 중점으로 한 중재 프로그램이 필요하다.

본 연구결과는 향후 뷰티전공 대학생의 정신건강프로그램의 기초 자료로 사용될 수 있다. 또한 향후 뷰티전공 대학생에게 Covid-19와 같은 신종 감염병 예방 교육 시 본 연구에서 확인된 변수들을 고려하 여 대상자들에게 체계적인 교육과정을 개발하고 건강한 정신건강을 유지할 수 있을 것이다. 신종 감염병의 세계적인 범 유행은 정신건강 에 영향을 미치므로 이러한 예측하지 못한 특수한 상황 속 정신건강 프로그램을 위한 실제적 요구 조사와 교육현장에 적용하기 위한 논의 가 필요하다.

\section{Author's contribution}

MJA reviewed literature, performed questionnaires, analyzed the data and wrote the manuscript.

\section{Author details}

Mi-Jeung Ahn (Lecturer), Department of Nursing, Andong National University, 1375, Gyeongdong-ro, Andong-si, Gyeongsangbuk-do 36729, Korea.

\section{References}

Ahn MJ, Park SJ. Mediation effect of self-efficacy on the relationship between knowledge of and compliance with hand washing in cosmetology students. Asian Journal of Beauty and Cosmetology, 17: 277-286, 2019.

Ahn MJ. Knowledge, attitude, and prevention practice of cosmetology students toward Covid-19 infectious disease. Asian Journal of Beauty and Cosmetology, 19: 459-466, 2021.

Anderson JL, Warren CA, Perez E, Louis RI, Phillips S, Wheeler J, Cole M, Misra R. Gender and ethnic differences in hand hygiene practices among college students. American Journal Infect Control, 36: 361-368, 2008.

Hwang SJ, Lee MI. Perceived knowledge, anxiety and compliance with preventive behavior performance on COVID-19 by nursing college students. Journal of Digital Convergence, 18: 459-468, 2020.

Holmes EA, O' Conner RC, Perry VH, Tracy I, Wessely S, Arseneault L, Ballard C, Christin H, Silver RC, Everall I, et al. Multidisciplinary research priority for the COVID-19 pandemic: a call for action for mental health science. The Lancet Psychiatry, 7: 547-560, 2020.

Kim HR, Choi EY, Park SY, Kim EA. Factors influencing preventive behavior against coronavirus disease 2019 (COVID-19) among medically inclined college students. Journal of Korean Academy of Fundamentals of Nursing, 27: 428-437, 2020.

Kim JH, Yun JS. Park JY. A study of the knowledge and educational needs of college students about coronavirus disease-2019 and preventive behavior adopted against it. Journal of the Korean Society of Integrative Medicine, 9: 109-121, 2021.

Kim KS, Jeong JS, Choi SH. Survey for hygiene behavior on healthcare personnel by hygiene inventory 23. Korean Journal of Healthcare-Association Infection Control and Prevention, 17: 40-51, 2012.

Kim MS, Kang SK. A study on the effect of the COVID-19 pandemic on young people's mental health. Studies on Life and Culture, 60: 133-153, 2021.

Kissler SM, Tedijanto C, Goldstein E, Grad YH, Lipsitch M. Projecting the transmission dynamics of SARS-CoV-2 through the postpandemic period. Science, 368: 860- 
868, 2020.

Lee DH, Kim YJ, Lee DH, Hwang HH, Nam SK, Kim JY. The influence of public fear, and psycho-social experiences during the coronavirus disease 2019 (COVID-19) pandemic on depression and anxiety in South Korea. The Korean Journal of Counseling and Psychotherapy, 32: 2119-2156, 2020.

Lee SJ, Kim XL, Lee SJ. Factors influencing COVID-19 preventive behaviors in nursing students: knowledge, risk perception, anxiety, and depression. Journal of Korean Biological Nursing Science, 23: 110-118, 2021.

Lee JM. An exploratory study on effects of loneliness and YouTube addiction on college life adjustment in the distance education during COVID-19. The Journal of the Korea Contents Association, 20: 342-351, 2020.

Montazeri A, Vahdaninia M, Ebrahimi M, Jarvandi S. The hospital anxiety and depression scale (HADS): translation and validation study of the Iranian version. Health and Quality of Life Outcomes, 1: 14, 2003.

Oh SM, Min KJ, Park DB. A study on the standardization of the hospital anxiety and depression scale for Koreans: a comparison of normal, depressed and anxious groups. Journal of Korean Neuropsychiatric Association, 38: 289296, 1999.
Park N, Ryu JH, Nam M, So A. Knowledge of COVID-19, mental health status and prevention health behavior of university students' during COVID-19 pandemic. Journal of the Korean Society for Multicultural Health, 11:1-14, 2021.

Provenzano S, Santangelo OE, Armetta F, Pesco G, Allegro A, Lampasona M, Terranova A, D’Anna G, Firenze A. COVID-19 infection: comparing the knowledge, attitude and practices in a sample of nursing students. Acta Biomed for Health Professions, 91: e2020001, 2020.

Shin SH. Relationships between health promoting lifestyle, health belief about emerging infectious disease and hygiene behavior of college students. Journal of the Korea Convergence Society, 10: 285-293, 2019.

Sim MY. Psychological effects of the coronavirus disease 2019 pandemic. The Korean Journal of Medicine, 95: 360-363, 2020.

Stevenson RJ, Case TI, Hodgson D, Porzg-Drummond R, Barouei J, Oaten MJ. A scale for measuring hygiene behavior: development, reliability and validity. American Journal of Infection Control, 37: 557-564, 2009.

Zigmond AS, Snaith RP. The hospital anxiety and depression scale. Acta Psychiatrica Scandinavica, 67: 361-370, 1983. 


\section{국문초록}

\section{Covid-19에 대한 지식, 위생행위가 뷰티전공 대학생의 정신건강에 미치는 영향}

안미정

국립안동대학교 간호학과, 경상북도 안동시, 한국

목적: 본 연구는 뷰티전공 대학생의 Covid-19에 대한 지식, 위생행위을 확인하고 정신건강에 영향을 미치는 요인을 확인하고자 하 였다. 방법: 분석은 SPSS/WIN프로그램을 사용하였다. Covid-19에 대한 지식, 예방행위, 정신건강은 단변량 분석을 사용하였고, 정신건강에 영향을 미치는 요인은 Stepwise multiple regression을 사용하였다. 결과: 뷰티전공 대학생들의 정신건강에 영향을 주는 요인은 Covid-19와 관련된 지식, 주관적 건강인식, 아르바이트 유무로 확인 되었다. 결론: 본 연구를 통해 뷰티 전공 대학생의 정신 건강의 하위요인인 불안과 우울의 경계군과 심각군이 각각 $34.9 \%, 36.2 \%$ 로 확인 되었다. 추후 연구에서는 표본과 영향요인을 확대 하여 분석하는 것이 필요하다고 생각된다.

핵심어: 코로나 19, 지식, 위생행위, 정신건강, 뷰티전공 대학생

\section{참고문헌}

김광순, 정재심, 최상호. 위생척도 Hygiene Inventory 23을 이용한 병원직원의 위생행위 조사. 의료관련감염관리, 17: 40-51, 2012.

김미숙, 강선경. Covid-19 대유행이 청년세대의 정신건강에 미치는 영향. 생명연구, 60: 133-153, 2021.

김진희, 윤정숙, 박재영. 코로나바이러스 감염증-19(Covid-19)에 대한 대학생의 지식, 교육요구도 및 예방행위 수행도. 대한통합 의학회지, 9: 109-121, 2021.

김해란, 최은영, 박신영, 김은아. 보건의료계열 학생의 코로나바이러스 감염증-19 예방행동에 영향을 미치는 요인. 기본간호학회 지, 27: 428-437, 2020.

박나라, 류지홍, 남민아, 소애영. Covid-19 세계적 대유행으로 인한 대학생의 지식, 정신건강실태 및 감염예방행위. 다문화건강학 회지, 11: 1-14, 2021.

신선화. 대학생의 건강증진 생활양식, 신종감염에 대한 건강신념 및 위생행위간의 관계. 한국융합학회논문지, 10: 285-293, 2019. 심민영. 코로나바이러스 감염증-19와 관련된 정신건강문제. 대한내과학회지, 95: 360-363, 2020.

안미정, 박선주. 미용계열 대학생의 손씻기 지식과 수행의 관계에서 자기효능감의 매개효과. 아시안뷰티화장품학술지, 17: 277286, 2019.

안미정. 뷰티전공 대학생의 Covid-19에 대한 지식, 태도, 예방실천. 아시안뷰티화장품학술지, 19: 459-466, 2021.

이동훈, 김예진, 이덕희, 황희훈, 남슬기, 김지윤. 코로나바이러스(Covid-19) 감염에 대한 일반 대중의 두려움과 심리, 사회적 경험

이 우울, 불안에 미치는 영향. 한국심리학회지: 상담심리치료, 32: 2119-2156, 2020.

이수진, 김향란, 이수진. 간호대학생의 코로나19 관련 예방행위 영향요인: 지식, 감염위험지각, 우울, 불안을 중심으로. Journal of

Korean Biological Nursing Science, 23: 110-118, 2021.

이종만. 코로나 19 원격 교육에서 외로움과 유튜브 과다사용이 대학생활적응에 미치는 영향에 대한 탐색적 연구. 한국콘텐츠학회논

문지, 20: 342-351, 2020.

오세만, 민경준, 박두병. 병원 불안-우울척도에 관한 표준화 연구: 정상, 불안, 우울 집단간 비교. 신경정신의학, 38: 289-296, 1999.

황순정, 이명인. 간호대학생이 지각한 Covid-19의 지식, 불안이 예방행위 수행정도에 미치는 영향. 디지털융복합연구, 18 : 459-468, 2020. 


\section{中文摘要}

\section{COVID-19知识和卫生行为对美容专业大学生心理健康的影响}

安美貞

安东大学护理学科, 庆尚北道安东市, 韩国

目的: 本研究旨在确认美容学生对COVID-19的知识和卫生行为, 并确定影响心理健康的因素。方法: 分析采用 SPSS/WIN程序。对知识COVID-19、预防行为和心理健康采用单变量分析, 对影响心理健康的因素采用逐步多 元回归分析。结果：影响美容专业学生心理健康的因素被确定为与COVID-19相关的知识、主观健康感知和兼职 工作。结论: 本研究分别确定了 $34.9 \%$ 和 $36.2 \%$ 的边缘组和严重组的焦虑和抑郁, 它们是美容专业学生心理健康 的子因素。在未来的研究中, 认为有必要扩大样本和影响因素。

关键词: COVID-19, 知识, 卫生行为, 心理健康, 美容学生 
